\title{
RISIKO KECELAKAAN SEPEDA MOTOR PADA SIMPANG PRIORITAS
}

\author{
Benidiktus Susanto \\ Program Doktoral \\ Departemen Teknik Sipil \\ dan Lingkungan \\ Fakultas Teknik \\ Universitas Gadjah Mada \\ benidiktus.susanto@ugm.ac.id
}

\author{
Siti Malkhamah \\ Departemen Teknik Sipil \\ dan Lingkungan \\ Fakultas Teknik \\ Universitas Gadjah Mada \\ malkhamah@ugm.ac.id
}

\author{
Latif Budi Suparma \\ Departemen Teknik Sipil \\ dan Lingkungan \\ Fakultas Teknik \\ Universitas Gadjah Mada \\ lbsuparma@ugm.ac.id
}

\begin{abstract}
Traffic safety is an important requirement in highway planning and design. Many studies related to accident risk analysis have been carried out, but practical applications are still not widely found, especially for accident risk analysis at priority junctions. This study aims to determine the speed and acceleration of motorcyclist behavior entering a junction. It was conducted by measuring the speed of a motorcycle when entering the junction at $150 \mathrm{~m}, 100 \mathrm{~m}$, and 50 meters before the point of the potential conflict. If the critical gap is longer than the stopping distance (a combination of the reaction time and braking time), the motorcycle will be safe. The results showed that motorcyclist decelerates the speed when entering the junction. The change in speed starts at 50 to 100 meters before the conflict. Motorcyclists will be safe if the speed is less than $65.8 \mathrm{~km} / \mathrm{h}$ at 50 meters before entering the junction.
\end{abstract}

Keywords: traffic safety, accident risk analysis, priority junction, speed

\begin{abstract}
Abstrak
Keselamatan adalah faktor utama dalam perencanaan dan perancangan fasilitas jalan. Berbagai penelitian yang berhubungan dengan analisis risiko kecelakaan telah banyak dilakukan, namun aplikasi praktisnya masih belum banyak dijumpai terutama untuk analisis risiko kecelakaan pada simpang prioritas. Penelitian ini bertujuan untuk mengetahui perilaku kecepatan dan percepatan sepeda motor saat memasuki simpang, sehingga dapat dilakukan analisis terhadap potensi risiko sepeda motor saat memasuki simpang prioritas. Penelitian dilakukan dengan mengukur kecepatan sepeda motor saat memasuki simpang pada jarak $150 \mathrm{~m}, 100 \mathrm{~m}$, dan $50 \mathrm{~m}$ sebelum titik konflik. Apabila celah kritis lebih panjang dari jarak henti (gabungan dari pengaruh waktu reaksi dan waktu pengereman), maka sepeda motor tersebut dapat dikategorikan selamat. Hasil penelitian menunjukkan bahwa saat memasuki simpang sebagian besar sepeda motor melakukan perlambatan. Perubahan kecepatan mulai terjadi pada jarak antara 50 sampai 100 meter sebelum titik konflik. Sepeda motor akan aman apabila pada kecepatan sebelum simpang tidak melebihi $65,8 \mathrm{~km} / \mathrm{jam}$.
\end{abstract}

Kata-kata kunci: keselamatan lalu lintas, analisis risiko kecelakaan, simpang prioritas, kecepatan

\section{PENDAHULUAN}

Keselamatan merupakan pertimbangan utama dalam setiap desain jalan (Direktorat Jenderal Bina Marga, 1992). Salah satu bagian jalan yang rawan terhadap kecelakaan adalah simpang sebidang, yang merupakan merupakan pertemuan 2 atau lebih arus lalu lintas sehingga potensi konflik antarkendaraan sangat tinggi. Pada simpang dengan Alat Pemberi Isyarat Lalu Lintas (APILL), kecelakaan dapat terjadi pada saat gerakan arus yang bergabung (merging) maupun arus yang berpencar (diverging). Sementara itu, pada simpang 
tanpa APILL, kecelakaan lalu lintas dapat terjadi pada saat arus berpotongan (crossing) maupun merging dan diverging. Di beberapa negara, kecelakaan lalu lintas banyak terjadi pada simpang. Di Inggris, jumlah kecelakaan yang terjadi pada simpang prioritas mencapai sekitar sepertiga dari seluruh kecelakaan (Highway Agency, 1992).

Tingkat keselamatan dan efisiensi pemanfaatan persimpangan sangat bergantung pada keadaan geometris persimpangan dan cara pengendalian lalu lintas, misalnya sudut persimpangan, gradien, penggunaan lahan di sekitar persimpangan, persimpangan dengan lampu lalu lintas, pengaturan arah, lokasi halte bis, dan pengaturan parkir. Faktor-faktor yang memengaruhi desain persimpangan sebidang meliputi lalu lintas, topografi dan lingkungan, ekonomi, dan manusia (Direktorat Jenderal Bina Marga, 1992). Kebiasaan pengemudi atau pemakai jalan merupakan faktor manusia yang dipertimbangkan dalam desain persimpangan sebidang. Sementara itu, pertimbangan akan kebutuhan khusus bagi pengguna jalan merupakan hal yang penting dalam desain simpang prioritas (Highway Agency, 1992).

Sepeda motor merupakan kendaraan yang dominan di jalan-jalan di Indonesia. Pada tahun 2016, proporsi sepeda motor mencapai lebih dari 80\% (Subdirektorat Statistik Transportasi, 2016). Sementara itu, jenis kendaraan yang paling banyak terlibat dalam kecelakaan adalah jenis sepeda motor, yang mencapai 70\% dari total kecelakaan (Korps Lalu Lintas Kepolisian Republik Indonesia, 2013).

Tujuan penelitian ini adalah untuk mengetahui sebaran kecepatan sepeda motor saat memasuki simpang, percepatan atau perlambatan sepeda motor saat pengemudi melihat adanya potensi konflik di depannya, dan menganalisis risiko kecelakaan berdasarkan jarak sisa. Jarak sisa adalah jarak antara celah kritis dan jarak pengereman. Jarak pengereman pada studi ini dihitung berdasarkan waktu reaksi dan kemampuan pengereman.

Jenis kecelakaan yang paling sering terjadi di simpang, adalah belok kanan dari lengan minor $(27,4 \%)$, belok kanan dari lengan besar $(22,1 \%)$, dan tabrak belakang/hidung ke ekor $(19,7 \%)$. Terdapat perbedaan yang mencolok antara proporsi berdasarkan tipe kecelakaan untuk persimpangan sederhana dan persimpangan yang memiliki fitur tambahan. Jenis kecelakaan yang paling sering untuk persimpangan sederhana adalah tabrak belakang, sedangkan untuk persimpangan yang lebih kompleks, belokan kanan dari lengan minor adalah kecelakaan yang paling sering terjadi (Pickering at al., 1986).

Kecelakaan selalu ditandai dengan beberapa penyebab. Alinyemen jalan merupakan faktor pengaruh penting, yang meliputi jari-jari, rasio kurva berturutan, alinyeman vertikal, dan jarak pandang. Dalam banyak studi, ternyata kapasitas jalan kurang baik untuk menjelaskan fenomena kecelakaan.

Penyebab utama kecelakaan sebenarnya adalah perilaku pengemudi, yang terutama dipengaruhi oleh kepribadian, keterampilan, dan pengalamannya. Selain itu, kondisi eksternal, seperti kondisi cuaca, kondisi jalan, waktu, atau kondisi penerangan juga memengaruhi perilaku pengemudi. Karena itu, untuk menganalisis kecelakaan perlu dipertimbangkan interaksi antara nilai-nilai teknis dan faktor manusia (Muhammed, 1986). 
Penelitian ini dilakukan pada simpang prioritas di Jalan Jogja-Solo KM 13,5. Simpang ini merupakan pertemuan antara Jalan Jogja-Solo (mayor) dengan Jalan BerbahKalasan (minor). Jalan Jogja-Solo merupakan jalan nasional, dengan fungsi sebagai jalan arteri primer, sedangkan Jalan Berbah-Kalasan adalah jalan kabupaten, dengan fungsi sebagai jalan kolektor.
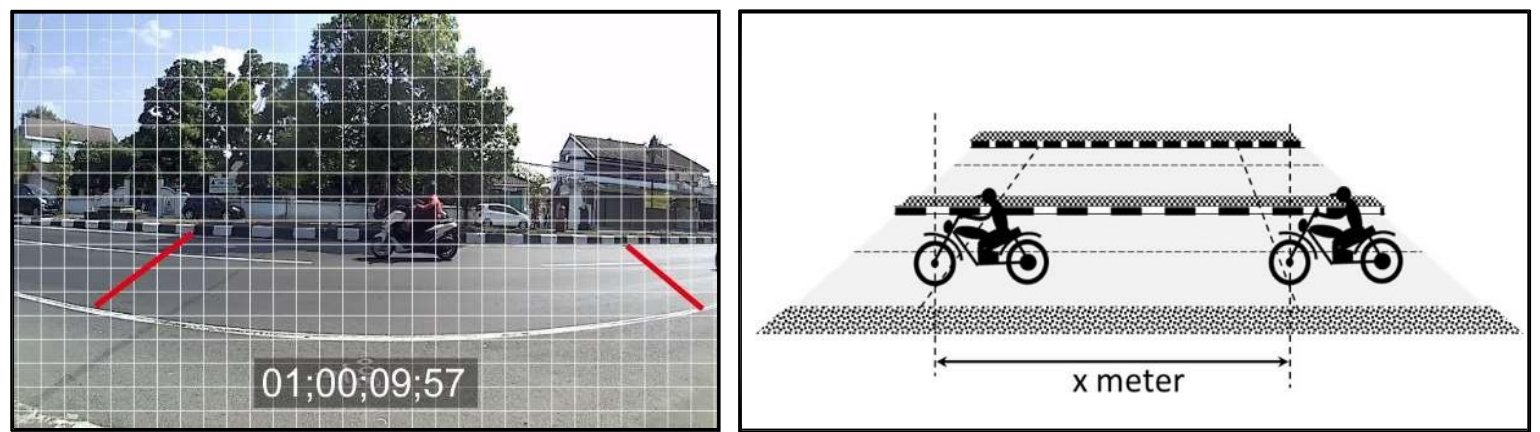

Gambar 1 Metode Pengukuran Kecepatan Sepada Motor

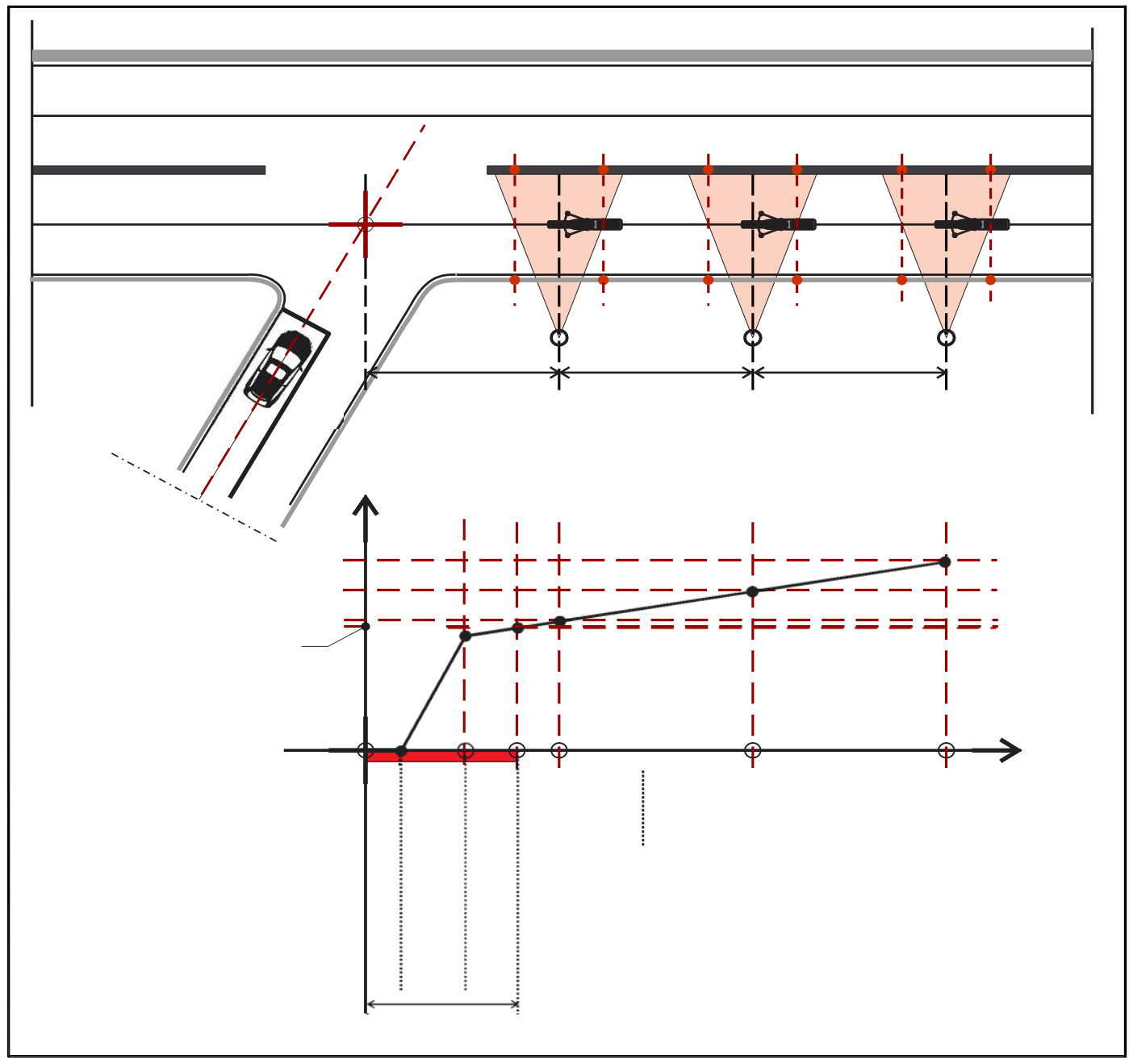

Gambar 2 Grafik Pengukuran Jarak Sisa 
Pengukuran kecepatan dilakukan terhadap 100 sepeda motor saat memasuki simpang prioritas dari arah jalan mayor dan terdapat kendaraan dari arah jalan minor yang akan melintas (belok kanan), dengan bantuan kamera video yang ditempatkan di tepi jalan, dengan jarak $50 \mathrm{~m}, 100 \mathrm{~m}$, dan $150 \mathrm{~m}$ dari simpang. Jarak tersebut dipilih berdasarkan lokasi rambu lalu lintas yang terpasang di ruas jalan. Asumsi yang digunakan adalah bahwa para pengemudi membaca rambu dan mengetahui bahwa mereka akan memasuki atau melewati simpang. Pada lokasi penelitian ini, rambu peringatan simpang berada pada jarak 125 meter dari simpang. Pengukuran kecepatan dilakukan pada titik yang berada sebelum dan setelah rambu. Waktu pengukuran adalah di luar jam puncak, yaitu pukul 10.00-11.00 WIB. Hal ini dimaksudkan untuk mempermudah pengukuran, karena volume lalu lintas relatif kecil, sehingga kendaraan dapat melaju dengan kecepatan bebas dan pada saat memasuki simpang tidak terhalang oleh antrian kendaraan saat terdapat kendaraan dari arah jalan minor memasuki simpang.

Pada masing-masing titik tersebut setiap sepeda motor yang melintas diukur kecepatannya, sehingga dapat diketahui percepatan atau perlambatan pada segmen tersebut. Hal ini dilakukan untuk mengetahui perilaku pengemudi sepeda motor saat melewati simpang. Dengan diketahui besarnya kecepatan dan percepatan atau perlambatan, dapat diketahui titik kritis pengemudi sepeda motor untuk dapat menghentikan kendaraannya dengan aman berdasarkan kemampuan perlambatan yang telah diteliti oleh peneliti sebelumnya.

\section{HASIL PENELITIAN}

\section{Kecepatan Sepeda Motor}

Kecepatan sepeda motor sangat bervariasi seperti ditunjukkan pada Tabel 1. Meskipun secara statistika dapat disimpulkan tidak terdapat perbedaaan kecepatan rata-rata sepeda motor pada jarak 150 meter, 100 meter, dan 50 meter dari titik konflik, namun ada kecenderungan pengemudi mengubah kecepatan sepeda motornya ketika memasuki simpang. Percepatan diperkirakan dilakukan pengemudi untuk segera melewati titik konflik sebelum kendaraan dari jalan minor memasuki simpang dan perlambatan dilakukan untuk melakukan antisipasi apabila kendaraan dari jalan minor mendadak memasuki simpang. Sebaran kecepatan pada jarak 50 meter cenderung lebih besar dibandingkan sebaran kecepatan pada jarak 100 m dan 150 meter. Pada jarak 50 meter kecepatan sepeda motor cenderung menurun.

Tabel 1 Kecepatan Rata-Rata Sepeda Motor Saat Mendekati Simpang pada Jarak 50 Meter dan 100 Meter dari Titik Konflik

\begin{tabular}{lrrrrrr}
\hline \multirow{2}{*}{ Nilai Statistik } & \multicolumn{2}{c}{ Jarak 50 Meter } & \multicolumn{2}{c}{ Jarak 100 Meter } & \multicolumn{2}{c}{ Jarak 150 Meter } \\
& \multicolumn{2}{c}{ dari Titik Konflik } & \multicolumn{2}{c}{ dari Titik Konflik } & \multicolumn{2}{c}{ dari Titik Konflik } \\
\cline { 2 - 7 } & \multicolumn{1}{c}{$\mathrm{m} / \mathrm{det}$} & $\mathrm{km} / \mathrm{jam}$ & $\mathrm{m} / \mathrm{det}$ & $\mathrm{km} / \mathrm{jam}$ & $\mathrm{m} / \mathrm{det}$ & $\mathrm{km} / \mathrm{jam}$ \\
\hline Rataan & 14,27 & 51,37 & 14,58 & 52,48 & 14,91 & 53,68 \\
Deviasi Standar & 2,69 & 9,67 & 2,47 & 8,89 & 2,54 & 9,16 \\
Nilai Maksimum & 21,00 & 75,60 & 21,00 & 75,60 & 22,11 & 79,58 \\
Nilai Minimum & 7,64 & 27,49 & 9,33 & 33,60 & 10,00 & 36,00 \\
\hline
\end{tabular}


Untuk menjamin keselamatan lalu lintas di Indonesia, pemerintah telah menetapkan batas kecepatan kendaraan tertinggi. Untuk jenis kendaraan sepeda motor pada ruas jalan arteri primer tanpa jalur lambat, kecepatan maksimum untuk sepeda motor adalah $60 \mathrm{~km} / \mathrm{jam}$ (Kementerian Perhubungan, 2015). Sementara itu, pada ruas Jalan Jogja-Solo KM 13,5, kecepatan tertinggi sepeda motor mencapai hampir $80 \mathrm{~km} / \mathrm{jam}$. Hal ini menunjukkan adanya potensi terjadinya kecelakaan yang melibatkan kendaraan sepeda motor pada jalan mayor akibat pelanggaran batas kecepatan maksimum tersebut.

\section{Percepatan Sepeda Motor}

Hasil penelitian ini menunjukkan bahwa perilaku pengendara sepeda motor pada saat melewati simpang, pada jarak antara 100 meter sampai 50 meter sebelum titik konflik, tercatat 55\% melakukan perlambatan, $28 \%$ melakukan percepatan, dan $17 \%$ berjalan konstan. Pada Gambar 2 dapat dilihat bahwa saat memasuki simpang, sebaran kecepatan pada jarak 150 meter dan pada jarak 50 meter lebih besar dibandingkan sebaran kecepatan pada segmen 100 meter. Hal ini dapat diindikasikan bahwa pada segmen 100 meter, pengendara sepeda motor mulai mempertimbangkan kecepatan untuk menghadapi rintangan yang mungkin terjadi di depannya. Pengendara sepeda motor dengan kecepatan yang tinggi cenderung mulai mengurangi kecepatannya, seperti terlihat pada Gambar 3, yang menunjukkan bahwa sebanyak 56\% pengendara mulai menurunkan kecepatannya pada segmen (100150) meter.
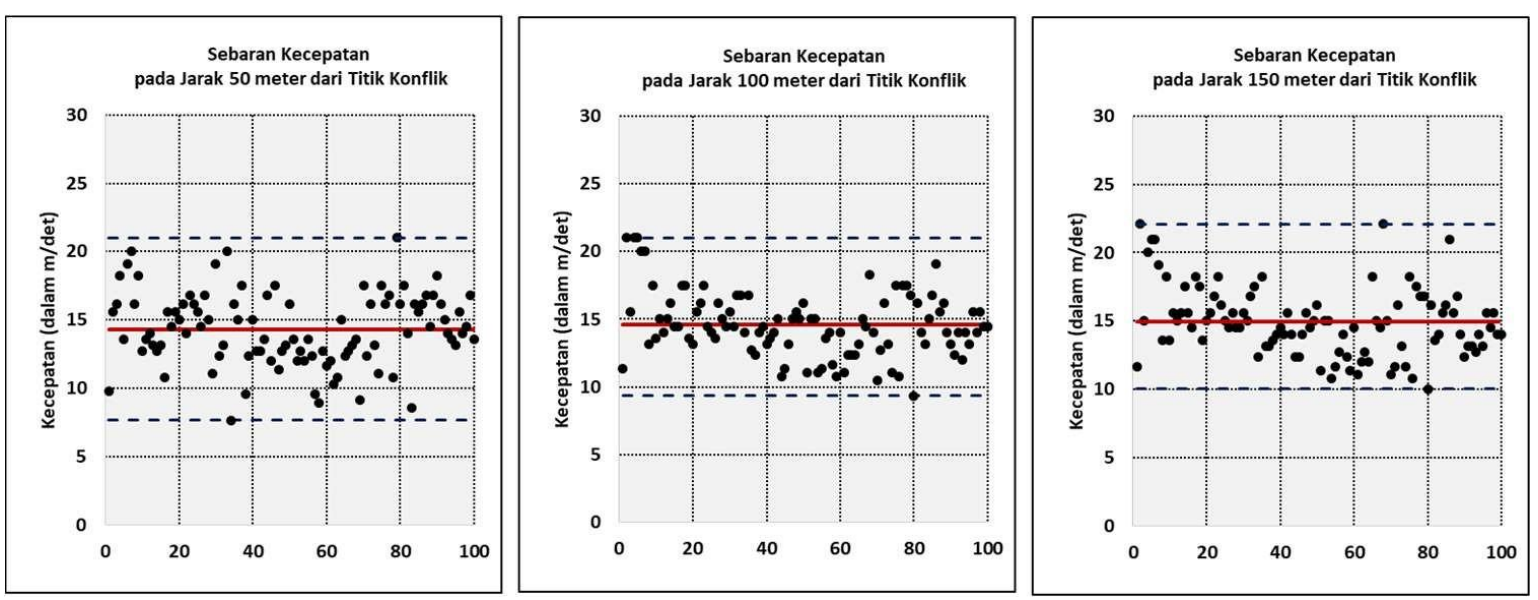

Gambar 3 Distribusi Kecepatan Sepeda Motor Saat Mendekati Simpang pada Jarak 50 Meter, 100 Meter, dan 150 Meter

\section{Analisis Risiko Kecelakaan}

Gambar 5 menunjukkan bahwa pada saat sepeda motor mendekati simpang, sebagian besar tidak melaju dengan kecepatan konstan. Hasil pengamatan di lapangan menunjukkan bahwa $82 \%$ kendaraan melaju dengan percepatan atau perlambatan tertentu. Hal ini berpengaruh terhadap jarak sisa ketika pengendara memutuskan untuk menghentikan kendaraannya sebelum titik konflik. 

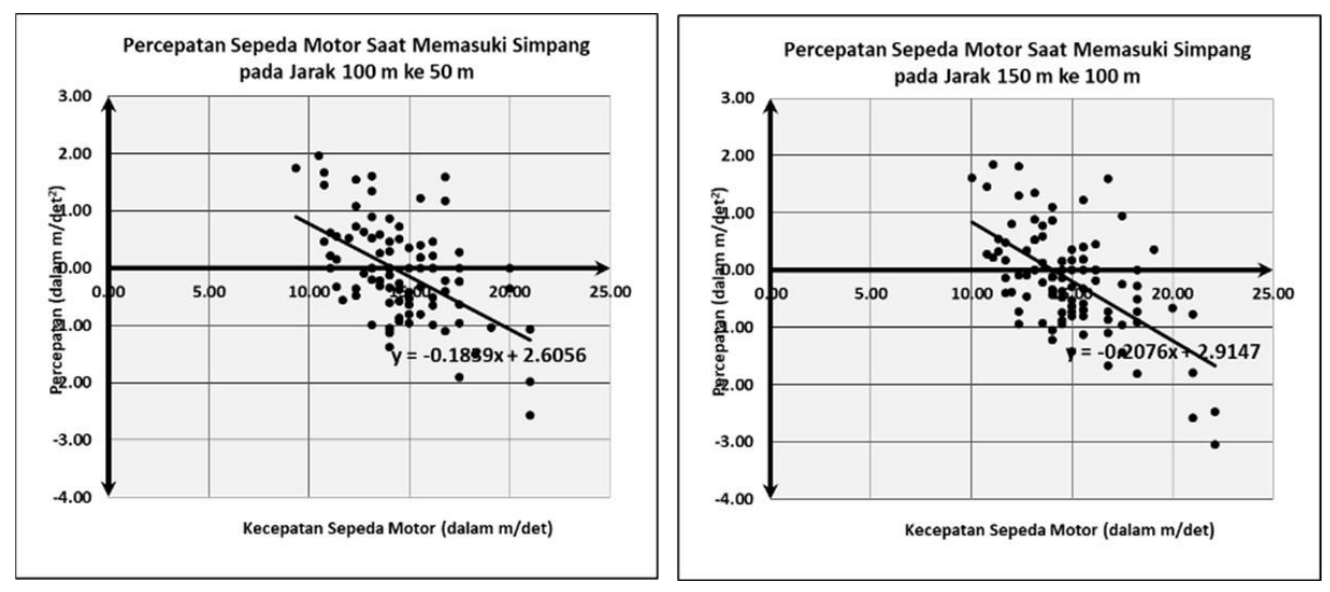

Gambar 4 Distribusi Percepatan Sepeda Motor Saat Memasuki Simpang
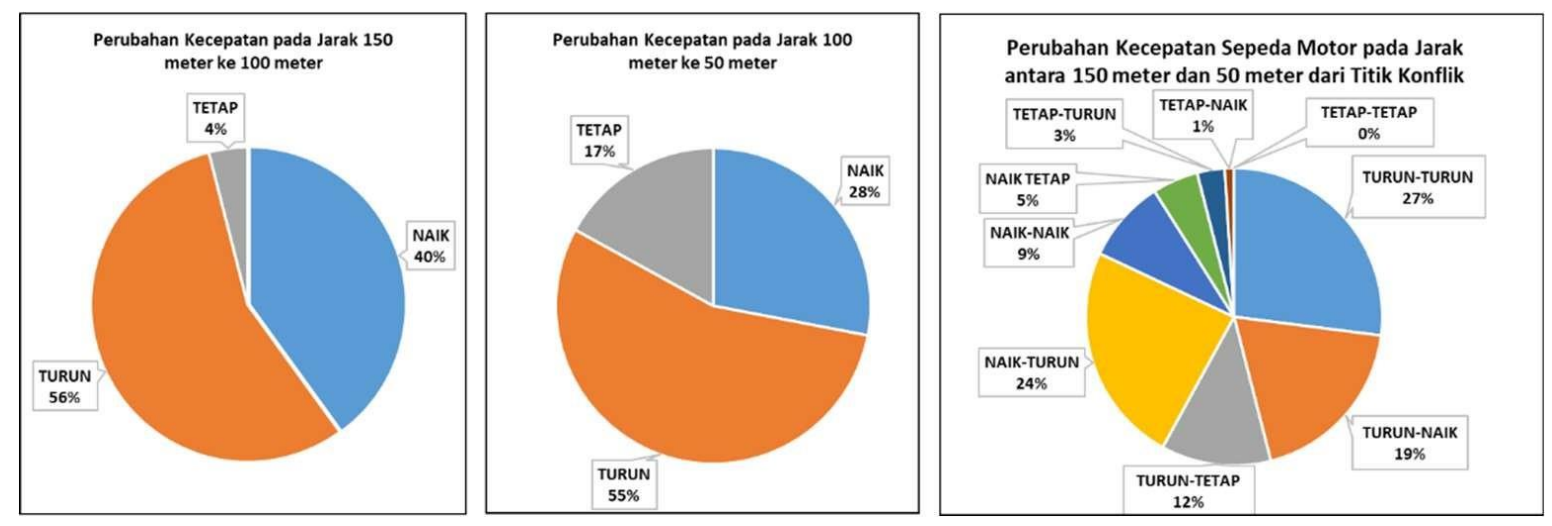

Gambar 5 Perubahan Kecepatan Sepeda Motor pada Jarak 150 ke 100 Meter dan 100 ke 50 Meter

Ketika kemunculan objek secara tiba-tiba atau situasi berbahaya terjadi dalam jarak dekat, pengemudi biasanya menurunkan gigi persneling secara instan, dengan waktu reaksi hampir nol. Saat menurunkan gigi persneling ini mesin kendaraan membuat laju kendaraan melambat (engine brake force) sebesar 1,6 m/det ${ }^{2}$. Sementara itu, setelah pengemudi sepeda motor memutuskan mengerem kendaraannya, perlambatan yang terjadi (deceleration rate caused by brake) sebesar $6,75 \mathrm{~m} / \mathrm{det}^{2}$ dengan deviasi standar 2,12 m/det ${ }^{2}$ (Costa et al., 2018b).

Sebelum membuat keputusan atas gangguan yang muncul di depannya, pengemudi membutuhkan waktu reaksi untuk mempercepat, memperlambat, menghentikan, atau melakukan manuver untuk menghindar. Waktu reaksi pengemudi sepeda motor di Yogyakarta adalah sebesar 0,53 detik dengan deviasi standar 0,23 detik (Costa et al., 2018b). Pada rentang waktu reaksi ini, kendaraan melaju dengan dengan kecepatan dan percepatan atau perlambatan yang sama dengan dengan kecepatan dan percepatan atau perlambatan saat pengemudi melihat objek.

Jarak sisa aman didefinisikan sebagai jarak yang masih tersisa ke titik konflik apabila pengemudi sepeda motor mulai bereaksi ketika kendaraan dari arah jalan minor bergerak memasuki simpang. Persamaan yang digunakan dalam perhitungan ini adalah persamaan- 
persamaan gerak lurus berubah beraturan. Perhitungan waktu sisa dimulai saat kendaraan berada pada jarak celah kritis. Jarak celah kritis ditentukan berdasarkan kecepatan dan percepatan kendaraan, serta nilai celah kritis, dalam satuan waktu, yang nilainya diambil dari hasil penelitian sebelumnya. Nilai waktu reaksi dan kemampuan pengereman sepeda motor digunakan dengan mempertimbangan nilai sebaran data hasil penelitian. Nilai-nilai yang dipilih adalah nilai kritis sebesar $85 \%$ dari seluruh data. Jarak aman sisa merupakan selisih antara jarak celah kritis dan jarak pengereman, termasuk jarak reaksi.

Untuk menganalisis potensi kecelakaan lalu lintas, jarak aman sisa dibandingkan dengan nilai celah yang dapat diterima minimum atau celah kritis kendaraan dari arah jalan minor. Beberapa penelitian mengenai celah kritis, baik yang dilakukan di Yogyakarta maupun di beberapa kota lainnya di Indonesia, menunjukkan bahwa nilai celah kritis sangat bervariasi, mulai dari 2,5 detik hingga 8,2 detik, seperti ditunjukkan pada Tabel 2. Pada studi ini, nilai celah kritis yang digunakan adalah nilai celah kritis dari hasil penelitian pada simpang tidak bersinyal di Yogyakarta, yaitu sebesar 2,7 detik.

Tabel 2 Hasil Penelitian Celah Kritis pada Simpang Tak Bersinyal di Beberapa Kota di Indonesia

\begin{tabular}{lcl}
\hline Kota Penelitian & Tahun Penelitian & \multicolumn{1}{c}{ Nilai Celah Kritis } \\
\hline Pontianak (Apriansyah et al., 2018) & 2018 & $(3,2-4,0)$ detik \\
Malang (Suraji, 2011) & 2011 & 5,0 detik \\
Manado (Maengkom et al., 2018) & 2018 & $(2.5-8,2)$ detik \\
Yogyakarta (Juniardi et al., 2010) & 2010 & $(2,7-2,94)$ detik \\
Yogyakarta (Costa et al., 2018a) & 2018 & 20 meter \\
\hline
\end{tabular}

Sepeda motor pada jalan mayor akan berada dalam kondisi aman apabila jumlah jarak reaksi dan jarak pengereman lebih kecil daripada jarak celah kritis. Gambar 6 menunjukkan bahwa sepeda motor akan aman apabila kecepatan kendaraan pada jarak 50 meter dari titik konflik tidak melebihi $65,8 \mathrm{~km} / \mathrm{jam}$. Dari data lapangan didapat sebanyak $7 \%$ sepeda motor melaju dengan kecepatan lebih tinggi dari $65,8 \mathrm{~km} / \mathrm{jam}$.

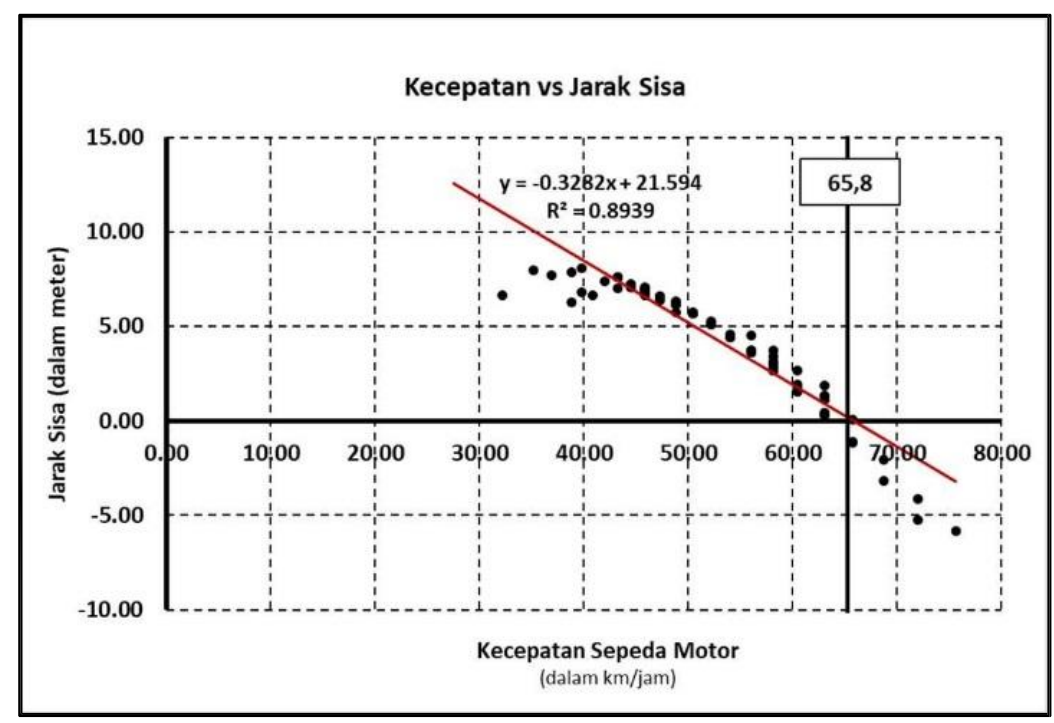

Gambar 6 Jarak Aman Sisa Berdasarkan Nilai Waktu Reaksi 
Apabila perilaku kecepatan pengendara sepeda motor saat memasuki simpang ini dapat dianggap sebagai perilaku umum pengendara saat memasuki simpang, dapat disimpulkan bahwa simpang tersebut cukup aman terhadap kecelakaan atau tabrakan antara sepeda motor pada jalan mayor dengan kendaraan dari jalan minor yang memasuki jalan atau belok kanan ke jalan mayor. Metode perhitungan ini dapat dikembangkan untuk menilai apakah suatu simpang tidak bersinyal cukup aman bagi kendaraan, khususnya sepeda motor, pada jalan mayor dan untuk memutuskan manajemen kecepatan yang akan dilakukan. Penelitian ini dapat dilanjutkan dengan menganalisis efektivitas manajemen kecepatan yang pernah dilakukan, sehingga dapat diterapkan pada simpang yang berpotensi terjadi kecelakaan.

\section{KESIMPULAN}

Dari hasil penelitian ini dapat disimpulkan beberapa hal sebagai berikut:

1) Sebaran kecepatan sepeda motor saat memasuki simpang prioritas sangat bervariasi dan cenderung menurun saat mulai memasuki simpamg prioritas pada jarak $50 \mathrm{~m}$ sampai 100 m dari simpang;

2) Perubahan kecepatan, percepatan dan perlambatan, mulai terjadi pada jarak 50 meter sampai 100 meter dari simpang, karena sebagian besar sepeda motor mulai mengurangi kecepatan atau melakukan perlambatan saat mendekati simpang; dan

3) Sepeda motor pada jalan mayor akan aman saat memasuki simpang apabila pada jarak 50 meter dari titik konflik mempunyai kecepatan tidak melebihi 65,8 km/jam.

\section{UCAPAN TERIMA KASIH}

Ucapan terima kasih disampaikan kepada Universitas Gadjah Mada yang telah membantu pendanaan penelitian ini melalui hibah program Penelitian Disertasi Doktor dan kepada Yayasan Slamet Rijadi Yogyakarta melalui Universitas Atma Jaya Yogyakarta yang telah memberikan beasiswa program doktor.

\section{DAFTAR PUSTAKA}

American Association of State Highway and Transportation Officials. 2011. A Policy on Geometric Design of Highways and Streets. 6th Ed. Washington D.C.

Apriansyah, D., Suyono, R.S., dan Azwansyah, H. 2018. Analisis Gap pada Persimpangan

Jalan di Pontianak. Jurnal Mahasiswa Teknik Sipil Universitas Tanjungpura, Vol. 5.

Costa, D.G.N.d., Malkhamah, S., dan Suparma, L.B. 2018a. Use of Systematic Approach in Accident Risk Analysis for Motorcyclists: A Conceptual Idea. Journal of Engineering and Technological Sciences, 50 (5): 607-623. 
Costa, D.G.N.d., Malkhamah, S., dan Suparma, L.B. 2018b. Use of the Safety Factor and Margin of Safety in Motorcyclist Accident Risk Management. International Journal of Technology, 4: 737-750.

Direktorat Jenderal Bina Marga. 1992. Tata Cara Perencanaan Persimpangan Sebidang Jalan Perkotaan. Jakarta: Direktorat Pembinaan Jalan Kota.

Fambro, D.B., Fitzpatrick, K., dan Koppa, R.J. 1997. NCHRP Report 400: Determination of Stopping Sight Distance. Washington, DC: National Academy Press.

Gates, T.J. dan Noyce, D.A. 2010. Dilemma Zone Driver Behavior as A Function of Vehicle Type, Time of Day, and Platooning. Transportation Research Record, 2149 (1): 84-93.

Hamzeie, R. 2016. The Interrelationships between Speed Limits, Geometry, and Driver Behavior: A Proof of Concept Study Utilizing Naturalistic Driving Data. Ames, IA: Iowa State University Capstone Programs.

Highway Agency. 1992. Design Manual for Roads and Bridges. Vol. 10. England: British Standards Institution.

Juniardi, Yulipriyono, E., dan Basuki, K.H. 2010. Analisis Arus Lalu Lintas di Simpang Tak Bersinyal (Studi Kasus Simpang Timoho dan Simpang Tunjung Kota Yogyakarta). Media Komunikasi Teknik Sipil, 18 (1): 1-12.

Kementrian Perhubungan. 2015. Peraturan Menteri Perhubungan Nomor 111 Tahun 2015 tentang Tata Cara Penetapan Batas Kecepatan. Jakarta: Kementrian Perhubungan Republik Indonesia.

Korps Lalu Lintas Kepolisian Republik Indonesia. 2013. Polantas dalam Angka 2013. Jakarta: Markas Besar Kepolisian Republik Indonesia, Korps Lalu Lintas.

Lamble, D., Laakso, M., dan Summala, H. 1999. Detection Thresholds in Car Following Situations and Peripheral Vision: Implications for Positioning of Visually Demanding In-Car Displays. Ergonomics, 42 (6): 807-815.

Maengkom, G.M., Timboeleng, J.A., dan Pandey, S.V. 2018. Analisis Kinerja Simpang Tak Bersinyal dengan Analisa Gap Acceptance dan MKJI 1997. Jurnal Sipil Statik, 6 (12): 1159-1166.

Malkhamah, S., Tight, M., dan Montgomery, F. 2005. The Development of Automatic Method of Safety Monitoring at Pelican Crossings. Accident Analysis \& Prevention, 37 (5): 938-946.

Muhammed, H.A. 2013. The Influence of Road Geometric Design Elements on Highway Safety. International Journal of Civil Engineering and Technology. Hlm. 146-162.

Pickering, D., Hall, R., dan Grimmer, M. 1986. Research Report 65: Accidents at Rural TJunction. Transport and Road Research Laboratory, Berkshire.

Smith, T., Garets, S., dan Cicchino, J. 2013. The Effect of Sight Distance Training on the Visual Scanning of Motorcycle Riders: A Preliminary Look. Washington: U.S. Department of Transportation, National Highway Traffic Safety Administration.

Subdirektorat Statistik Transportasi 2016. Statistik Transportasi Darat. Jakarta: Badan Pusat Statistik. 
Suraji, A. 2011. Analisis Sela Kritis (Critical Gap) Arus Lalu Lintas pada Simpang Tak Bersinyal. Widya Teknika, 19 (1): 5-11.

Ueckermann, A., Wang, D., MarkusOeser, dan Steinauer, B. 2015. Calculation of Skid Resistance from Texture Measurements. Journal of Traffic and Transportation Engineering, 2 (1): 3-16. 